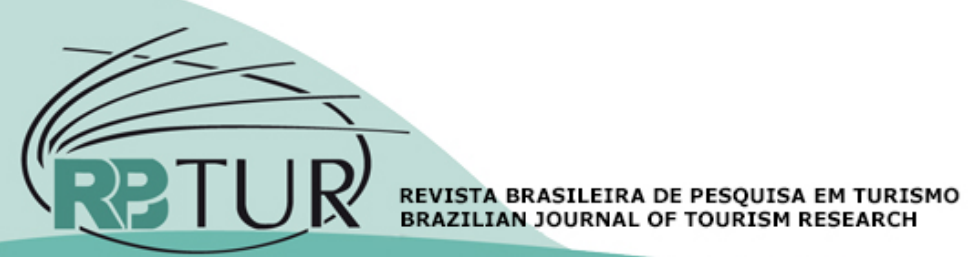

\title{
Papers
}

\section{Residents' Perceptions of the Impacts of the Rio 2016 Olympic Games: Before, During and After the Mega-Event}

\author{
Percepção dos Residentes sobre os Impactos dos Jogos Olímpicos Rio \\ 2016: Antes, Durante e Depois do Megaevento
}

\section{Percepción de los Residentes sobre los Impactos de los Juegos Olímpicos Rio 2016: Antes, Durante y Despues del Megaevento}

\author{
Deborah Moraes Zouain1; Paola Bastos Lohmann²; Gabriela De Laurentis Cardoso³; Kaarina Barbosa \\ Virkki4; Marcela Cohen Martelotte ${ }^{5}$
}

\begin{abstract}
1 Tourism Research Center UNIGRANRIO, Rio de Janeiro, Brazil;
2 University of Aveiro (UA), Aveiro, Portugal;

3 Tourism Research Center UNIGRANRIO, Rio de Janeiro, Brazil;

4 Tourism Research Center UNIGRANRIO, Rio de Janeiro, Brazil;

${ }^{5}$ Fluminense Federal University (UFF), Rio de Janeiro, Brazil.
\end{abstract}

\section{Keywords:}

Rio 2016;

Olympic Games;

Mega-event:

Host Community;

Perception.

Palavras-chave :

Rio 2016;

Olimpíada;

Megaevento;

Residentes;

Percepção.

\section{Abstract}

This study investigates the residents' perceptions of Rio de Janeiro regarding the impacts of Rio 2016 Olympic Games. For the first time, a country in South America was chosen to host this megaevent, being a great opportunity to track residents' perception and cover a gap in longitudinal studies involving residents in developing countries and its impacts on the host city. A face-to-face quantitative survey was conducted over three years, with a total of 1,211 interviewees in the city of Rio de Janeiro. The population perceived positively mainly an improvement in urban mobility and an increase in tourism; but, negatively, the misuse of public resources, increase in prices, and non-lasting legacies that critically affected the image of the destination post-Olympics.

Resumo

Este estudo analisa as percepções dos residentes do Rio de Janeiro em relação aos impactos dos Jogos Olímpicos Rio 2016. Pela primeira vez, um país da América do Sul foi escolhido para sediar esse megaevento, sendo uma ótima oportunidade para rastrear a percepção da população local e cobrir uma lacuna em estudos longitudinais envolvendo residentes em países em desenvolvimento e seus impactos na cidade-sede. Um levantamento quantitativo face a face foi realizado ao longo de três anos, com um total de 1.211 entrevistados na cidade do Rio de Janeiro. A população percebeu positivamente principalmente uma melhoria na mobilidade urbana e um aumento no turismo; mas, negativamente, o uso indevido de recursos públicos, aumento de preços e legados não duráveis que afetaram criticamente a imagem do destino pós-Olimpíadas. 
Palabras clave:

Rio 2016;

Juegos Olímpicos;

Megaevento;

Comunidad receptora;

Percepción.

Peer-reviewed article. Received in: 31/10/2018. Accepted in: 04/02/2019.
Resumen

Este estudio analiza las percepciones de los residentes de Río de Janeiro en relación a los impactos de los Juegos Olímpicos Río 2016. Por primera vez, un país de América del Sur fue elegido para albergares e megaevento, siendo una excelente oportunidad para rastrear la percepción de la población local y, cubrir una brecha en estudios longitudinales que involucren a residentes en países en desarrollo y sus impactos en la ciudad sede. Un relevamiento cuantitativo face to face fue realizado a lo largo de tres años, con un total de 1.211 entrevistados en la ciudad de Río de Janeiro. La población percibió positivamente principalmente una mejora en la movilidad urbana y un aumento en el turismo; pero, negativamente, el uso indebido de recursos públicos, aumento de precios y legados no duraderos que afectaron críticamente a la imagen del destino post-Olimpiadas.

How to cite: Zouain, D. M.; Lohmann, P. B.; Cardoso, G. L.; Virkki, K. B.; Martelotte, M. C. (2019). Residents' Perceptions of the Impacts of the Rio 2016 Olympic Games: Before, During and After the Mega-Event. Revista Brasileira de Pesquisa em Turismo, São Paulo, 13 (2), p. 93 - 112, maio/ago. http://dx.doi.org/10.7784/rbtur.v13i2.1554

\section{INTRODUCTION}

The Olympic Games are the most significant event in the world due to their impact on the economy, society, and politics of the host country or city (Toohey \& Veal, 2000, in Zhou \& Ap, 2009: 78). On October 2, 2009, Rio de Janeiro was announced as the host of the 2016 Olympic and Paralympic Games. From that date onward, great expectations arose about how much the city could develop and structure itself for the different stakeholders who experience it daily. Such a sentiment was understandable because the word legacy was often used when discussing the transforming powers behind this mega-event (Gelan, 2003; Zhou \& Ap, 2009), especially in regard to the creation of new urban infrastructure, transport, technology, communication, sport, increased tourism, promotion of the city's image, and attracting international capital, thus generating economic and social benefits (Kim \& Jun, 2016).

The literature indicates that mega-events are unique events that tend to have profound long-term effectsboth positive and negative-on host cities, which results in significant economic, cultural, and political impacts (Cho \& Bairner, 2012; Dansero \& Puttilli, 2010; Davies, 2012; Porter \& Fletcher, 2008; Preuss \& Solberg, 2006). These events can also promote the identity of a city or region on a global scale (Essex $\&$ Chalkley, 2010; Bull \& Lovell, 2007; Chalip \& Costa, 2005), shape world tourism standards (Fourie \& Santana-Gallego, 2011), stimulate economic growth (Dwyer, Forsyth, \& Spurr, 2004), build social capital (Gibson et al., 2014), and change the quality of life and well-being of residents (Kaplanidou, 2012; Kaplanidou et al., 2013).

According to van Niekerk (2017), the organization of events and festivals has been the strategy most used by tourist destinations that seek differentiation in the market. However, for most destinations, these strategies have not been developed in an integrated manner.

Barcelona is one of the most obvious success cases of sporting mega-events, with the 1992 Olympic Games being a reference model. However, according to Lindau, Petzhold, Tavares, and Facchini (2016), this success is very much associated with the fact that the public administration at the time understood that the Games should serve the city and not vice versa.

Considering the positive externalities associated with mega-events, many countries, regions, and cities have adopted policies that prioritize competing as a host destination, even if the task requires considerable investment of human, financial, and physical resources from the community (Gratton, Shibli, \& Coleman, 2005). The excellent opportunities and benefits have led many countries to host the Games, which explains why residents are often willing to support and pay for sporting mega-events (Vetitnev \& Bobina, 2015). Although the contribution of these events to regional economic development is debatable (Chou, 2013; Humphreys \& 
Prokopowicz, 2007), the enthusiasm for hosting them is evident in the growing number of proposals presented by cities and countries with developing economies (Huang \& Lou, 2010; Mao \& Huang, 2015).

It is a fact that the process of hosting a mega-event is complex and requires effort from various stakeholders (e.g. government and private, national, and international initiatives), and in particular, there is a clear need for ever-increasing involvement of the community, not only to facilitate staging the event but also to create a lasting impact on society (Faulkner \& Tideswell, 1997; Gursoy \& Kendall, 2006; Huang \& Zhang, 2012; Kaplanidou, 2012; Nunkoo \& Gursoy, 2012; Al-Emadi et al., 2016). For Siegfried and Zimbalist (2000), the decision to designate part of the public budget for staging sporting mega-events precludes the opportunity to prioritize other areas of the budget, notably areas of social demand.

As suggested by the literature, hosting a mega-event does not involve only the local or regional governments but also the participation of business corporations. Thus, lucrative alliances tend to be established between business elites and local politicians. For Malfas, Theodoraki, and Houlihan (2004), these alliances usually involve, among other things, campaigns to convince the citizens of the host city-as in the case of the Olympic Games-that the event will transform the city, thus justifying the use of tax money and making them believe that such benefits outweigh the costs (Chen \& Tian, 2015). Attitude and support are generally considered to be interchangeable factors in the analysis of the reactions of residents to sporting mega-events. Previous studies have measured support based on indications of general attitude (Chen, 2010; Mihalik \& Simonetta, 1999; Zhou \& Ap, 2009). The support of the community often depends on the perceived benefits and costs (Deccio \& Baloglu, 2002; Prayag et al., 2013)-these maybe economic and involve the awareness of the generation of a long-term legacy (Jeong \& Faulkner, 1996; Mihalik \& Simonetta, 1998; Ritchie \& Lyons, 1990; Soutar \& McLeod, 1993; Chen \& Tian, 2015).

As the local residents involved in mega-events are vital to the short- and long-term success of the hosted event, their perceptions of the social impact of these events are essential to their success (Mao \& Huang, 2015; Chen \& Tian, 2015; Vetitnev \& Bobina, 2015; Prayag et al., 2013, Gursoy et al., 2016). Furthermore, because residents of the host cities are often the ones that are most impacted by the direct and indirect effects of mega-events, they are key stakeholders during the different phases of the event, especially due to their perceptions regarding meeting demands, improvements, wastes, facilities created, inconveniences suffered, and possible future benefits-the latter being a topic that requires more in-depth research (Kaplanidou, 2012). Additionally, identifying the opinions and attitudes of residents in relation to the Olympics gives the Games' organizers a better understanding of public concerns in the planning and preparation phase of the Games (Zhou \& Ap, 2009; Vetitnev \& Bobina, 2015).

Thus, this study had two main objectives. The first was to evaluate the perception of residents regarding the impacts of the 2016 Rio Olympic Games, considering three distinct periods: before, during, and after staging the sporting mega-event. The second was to validate-by means of an empirical study, with the collection of primary data-what the literature indicates as positive and negative aspects of sporting mega-events, taking as target audience residents of a developing country. Lorde, Greenidge, and Devonish (2011) emphasized that mega-events have long-term impacts and that their costs and benefits are perceived by residents years later (Gursoy et al., 2011). It took three years to collect the data analysed in the present study.

The present study also aimed to cover three gaps identified after extensive review of the literature. The first is related to the development of longitudinal studies of sporting mega-events. The second involves analysing the perception of residents in the context of developing countries. Zhou and Ap (2009) indicated that much of the literature that investigates the perception of residents is conducted in the context of developed countries because according to Getz (1997), developing countries only began to host sporting mega-events in the previous 20 years. Lastly, this study aims to cover the third gap, which is related to the importance of considering the resident in the development of Olympic Games studies, given that the resident is an important stakeholder in the context of territorial innovation.

Understanding that for innovation to occur, there is a need for greater interaction between different stakeholders in society, Rodrigues and Melo (2012) noted that the triple helix model (THM) is increasingly used as a source of inspiration for local development policy. The first helix encompasses academia/university, the second helix refers to industry, and the third to government. To this model, Carayannis and Campbell (2014) added civil society as an important stakeholder in terms of supporting, promoting, and advancing knowledge 
(research) and the application of knowledge (innovation). In this case, the resident plays a key role in the different staging steps of the mega-event, together with academia, universities, and the government.

Considering different perceptions in relation to mega-events is essential for generating accumulated knowledge that also allows rethinking: the use of the mega-event as a development strategy for hosting cities and the importance of involving the different stakeholders in the formulation of public policies related to events. For the preparation of the article, an extensive review of the literature on impacts of sporting megaevents-presented below-was first conducted. The methodology of the study is described in the following section, and then the results of the study are presented. Finally, the discussion, practical implications for future editions of the Olympic Games and host cities of sporting mega-events, and limitations and recommendations for future studies are presented.

\section{THEORETICAL FRAMEWORK}

Staging the Olympic Games generates various types of impacts for the host city and its surroundings. When a city is a candidate to host the event, a commitment is signed with the International Olympic Committee (IOC) to have in place the necessary structure for holding the Games, not only in terms of the construction of arenas and competition venues but of all of the infrastructure to receive the delegations, as well as transport, safety, technology, medical centres, urban mobility, and accessibility, among various other elements. Legacies can include a number of initiatives and programmes that include economic, social, and environmental aspects. These legacies appear to be developed based on the needs of each host community and its cultural, social, and economic context (Owen, 2005; Preuss, 2004; Toohey \& Veal, 2007).

For any host city, the Olympic Games offer opportunities for urban, economic, and social development, along with environmental interventions that propose to improve quality of life (Gratton \& Preuss, 2008; Preuss, 2007a, 2007b; Toohey \& Veal, 2007; Waitt, 2003). In the context of the Olympic Games (Waitt, 2003), the results of the concrete (tangible) legacy can be perceived as a more significant factor in the residents' perceptions of quality of life, given their direct role in the exchange process (i.e., results) when compared to the results of the abstract (intangible) legacy.

Such legacies relate to economic, social, and environmental impacts, which according to the results documented in the literature include: increased employment, tourism, spending in the community, and taxation returns (Horne, 2007; Karadakis, Kaplanidou \& Karlis, 2010; Owen, 2005; Whitson \& Horne, 2006); the development of infrastructure such as transportation, accommodation, hotels, sport venues, facilities, parks and recreation, media centres, tourist attractions, and airports (Chappelet, 2008; Hiller, 2006; Jones, 2001; Solberg \& Preuss, 2007); and other benefits through the generation of additional sources of income and more job opportunities.

Studies have concluded that the perceptions of positive and negative impacts that a mega-event should generate are the main determinants of the support/opposition of residents towards hosting mega-events in their community (Gursoy et al., 2011). The literature provides strong evidence that perceptions of a positive impact significantly and positively affect residents' support, whereas perceived negative impacts significantly and negatively influence support for mega-events (Zhou \& Ap, 2009).

For example, a longitudinal study by Getz (1994) showed that the support of residents for tourism is related to perceived positive impacts outweighing perceived negative impacts (Pappas, 2014). However, several factors, including, but not limited to, expected personal benefits, attachment to the community, level of involvement in community issues, distance from the event, sociodemographic variables, etc., can influence the level of support (Jurowski \& Gursoy, 2004). For example, studies suggest that residents who expect to receive personal benefits from a mega-event are more likely to favour and support hosting the event compared to those who expect to receive little or no benefit (Zhou \& Ap, 2009).

Certainly, these changes may depend on the portfolio of needs of each host city and the existing infrastructure and environmental resources, as the studies of Andranovich, Burbank, and Heying (2001) and Smith (2005) suggested. Although the term legacy has a positive connotation, the literature discusses some of the negative aspects of hosting the Games, covering economic, social, and environmental aspects (Chappelet, 2008; Kaplanidou \& Karadakis, 2010; Mangan, 2008). 


\section{a. Positive impacts of sporting mega-events}

Mega-events tend to create long-term benefits, such as improving the identity of a city's brand and its global status, in addition to strengthening social structure and improving social cohesion and the identity of the community (Balduck et al., 2011; Karadakis \& Kaplanidou, 2012; Walton, Longo, \& Dawson, 2008). For Capel (2010), staging a sporting mega-event generates many diverse positive effects and can be a powerful tool for urban marketing strategies, used by local administrations as a way of inserting the localities into the global economy. For individual residents, mega-events are also likely to provide new recreational opportunities, create new learning opportunities, inspire interest in sport, improve the availability of recreational facilities, and build civic pride.

For Souza et al. (2013), the country's international visibility increases with mega-events, and public order and safety become aspects that tend to affect the country's image and its ability to conduct an event in an organized and peaceful manner. In other words, the image and ability of the governments are on display in relation to issues of public safety and order. Thus, governments tend to make large investments in public safety, as happened in Brazil, with the expansion of pacifying police units (Unidades de Polícia Pacificadoras - UPPS), the training of police forces, and the purchase of safety equipment valued in the millions.

The growth of sport and event tourism has led to a significant increase in research on the impacts of sporting events (Gursoy \& Kendall, 2006; Al-Emadi et al., 2016). Preuss (2006) showed that it is not only the public authorities that seek positive legacies but also international sporting entities. The main justifications include the fact that a positive legacy prevents public discontent, justifies the use of public resources in the preparation of the event, and encourages other nations to host mega-events.

The changes that occur are also important for the economic impacts, as observed by Gursoy and Kendall (2006), who considered that community pride and international recognition are as significant for the economic impacts as for the quality of life of the residents. Moreover, they also contribute to the feeling of connecting the residents with the global public (Horne, 2007; Whitson \& Horne, 2006). This interaction can then further increase residents' sense of community, creating social impacts that, among other things, include improvement in the living conditions of populations and disadvantaged areas (Carey et al., 2011).

Hennessey et al. (2010) also found that, as part of integrated marketing campaigns, advertisements stimulate tourists' intentions to visit a destination. The components of the promotional ads and the interest in visiting a destination include special events created by the tourist industries and public and private sectors of the destination (Middleton, 1988).

Hypothesis1: Mega-events tend to create long-term benefits such as business opportunities, employment, and increased tourism.

Hypothesis 2: Mega-events help to strengthen the image of the destination.

Hypothesis 3: Mega-events increase residents' interest in sport.

Hypothesis 4: Mega-events improve the perception of safety with regard to the destination.

\section{b. Negative impacts for residents}

It is important to note that the image of the country that remains after staging the mega-event can have both positive and negative connotations (Kim \& Jun, 2016). Accordingly, some cities are remembered for the debt incurred, as is the case of the 1976 Olympic Games, which resulted in great losses and debt for the city of Montreal. By contrast, some cities are known for their surplus, such as Calgary and the 1988 Winter Olympics, which recorded a profit of more than 130 billion dollars, as stated by Whitson \& Horne (2006, as cited in Souza et al., 2013).

Thus, in this context, the planning process will be seen as an element that is of great importance because it seeks to achieve long-sought social, cultural, and ecological sustainability, and through these, the economic development of the place, as indicated by Santos \& Souza (2012). Perhaps the fact that the planning of the 
legacy is an integral part of the bidding requirements of the IOC for the cities that wish to host the Olympic Games (International Olympic Committee, 2011) has fuelled the academic discussion.

Social impacts can be conceptualized as any force that potentially influences the quality of life of the local residents (Balduck, Maes, \& Buelens, 2011; Haley, Snaith \& Miller, 2005; Deccio \& Baloglu, 2002; Gursoy \& Kendall, 2006; Kaplanidou et al., 2013; Gursoy et al., 2016), and these are perceived as greater than the economic benefits, especially when occurring in developing countries (Huang \& Zhang, 2012; Humphreys \& Prokopowicz, 2007; Pranic, Petric, \& Cetinic, 2012; Mao \& Huang, 2015). However, there is also evidence of negative impacts with large-scale developments; for example, gentrification in some areas of cities, the need to remove families, increased living costs, lack of maintenance of facilities, and real estate speculation. Additionally, there may be increased traffic congestion, increased prices, pressure on local law enforcement, and increased crime rates, which may reduce the amount of support (Mihalik \& Simonetta, 1998; Chen \& Tian, 2015).

With the construction of a large infrastructural base, it is natural for many construction projects to occur throughout the city, causing changes in the routine and mobility of the population. According to Bovy (2009), it is then assumed that a mega-event involves significant temporary changes in the life of the city that hosts it-in its logistics, organization of transport, and travel behaviour. The residents may also negatively evaluate the possibility of hosting a mega-event, as it may have a negative impact on the environment (Gursoy, Chi, $\mathrm{Ai}, \&$ Chen 2011) through increased pollution and deterioration of cultural, historical, and natural resources (Kim et al., 2006). From an economic standpoint, the allocation of funds for the construction of the Olympic Games infrastructure can be perceived as a rather significant waste (Jones, 2001; Whitson \& Horne, 2006) and can create opportunity costs (Kaplanidou \& Karadakis, 2010). For example, the funds that would have been invested in education or health are invested in infrastructure related to the Olympic Games and, therefore, may cause a negative reaction among the residents (Owen, 2005; Toohey, 2008). To cover costs, tax increases may occur (Gursoy \& Kendall, 2006; Solberg \& Preuss, 2007), which may also affect the local community.

There is also the possibility of generating negative short-term social impacts, such as antisocial behaviour towards visitors, and a number of other changes as well as an increased incidence of crime and the discomfort of residents due to congestion and crowding during the Games (Bull \& Lovell, 2007; Gursoy \& Kendall, 2006; Jones, 2001; Owen, 2005; Kim \& Jun, 2016). At Sochi 2014 and its nearby Olympic sites, the unprecedented scope of construction and associated dirt, traffic congestion, and disruption of water and electricity supply began to adversely affect the attitudes of the residents (Vetitnev \& Bobina, 2015). According to the study conducted by Chen and Tian (2015), during the 2008 Beijing Olympics, the increase in product prices became a significant concern among the residents of Beijing and Qingdao, which required immediate action by the authorities; for example, strengthening market supervision and increasing the supply of products and wages.

Gursoy, Chi, Ai, and Chen (2011) argue that some residents believe that hosting a mega-event may result in significant negative impacts on a host community such as direct expenditures and tax burdens and may shift public funds to private interests. According to Hiller (1990), critics argue that the reality of organizing the Olympic Games is that urban citizens receive relatively little tangible or direct benefit and may even have additional costs from the event. Mega-events run the risk of generating enormous excessive costs, and not all legacies are positive. Kim and Petrick (2005) also argue that not all residents are likely to fully support mega-events. Some residents may oppose the idea of hosting a mega-event due to their belief that the cost of hosting such events can be significantly higher than the economic benefits they are supposed to generate (Giesecke \& Madden, 2007). Additionally, hosting these events can also result in social, cultural, and environmental problems (Lorde, Greenidge, \& Devonish, 2011; Gursoy et al., 2016).

Hypothesis 5: Mega-events cause price increases at the host destination.

Hypothesis 6: Mega-events cause impacts on the routine of residents and on traffic.

Hypothesis 7: Mega-events cause financial losses. 


\section{c. Planning of sporting mega-events and territorial innovation}

Planning to prepare cities to host mega-events should take into account "quality infrastructure and investment in public services, especially in the control of public safety, traffic, demographics, hospitals, sanitation, and street cleanliness, as well as airports, convention centres, and tourist facilities, in order to offer tourists comfort and confidence during their stay" (Castro, 2010). Legacies with a social dimension must be planned and include, in particular, opportunities for community involvement in all relevant activities of the event as well as community pride, social cohesion, enthusiasm (Waitt, 2003), greater interaction, and strengthening of its image and awareness (Bull \& Lovell, 2007; Solberg \& Preuss, 2007).

According to the study of Zhou and Ap (2009), the integration of top-down and bottom-up development planning approaches is of great importance for government and event organizers to help them fully understand the concerns of residents and meet their needs. For example, that study found that approximately $93 \%$ of respondents reported that they were not consulted during the Olympic period and in the preparation process.

Thus, it is understood that the support of the local community plays an important role in the candidature process because the planners and companies must consider residents' viewpoints when evaluating the sustainability of their investments (Williams \& Lawson, 2001). The transformation of a mega-event into a vibrant urban party for both hosts and guests depends on the involvement of the people (Hiller, 1995), in which the individual perspectives of the residents determine how they perceive the main effects of the events, and their level of support is a direct result of their viewpoint (Prayag et al., 2013). Finally, local people actively shape the image of the event's location. For example, the friendliness and courtesy of the local people are strongly associated with the positive comments and spending of tourists, as indicated by Xie and Lee (2013).

For Rossi (2013), the incentive for different spheres of government to cooperate, through joint efforts and joint actions for solving problems, can facilitate decision making and make already existing projects viable, which otherwise could have taken years to be implemented. However, the preparation for the mega-event, which modifies the structure and daily life of a city, needs to benefit the entire population. In other words, although most of the spectators of the "live" sporting spectacle are not individuals with fewer resources, these individuals can benefit from the numerous actions that are part of the mega-event-workers who were employed in the construction and maintenance of the sporting facilities and infrastructure in general, citizens who begin using better quality collective transport and public sport and leisure facilities, etc. According to Preuss (2008, as cited in Lohmann, 2010, p. 50), this is part of the symbolic capital accumulated in the process.

Several researchers have examined the factors influencing the support of residents for mega-events (Prayag et al., 2013; Zhou \& Ap, 2009; Pappas, 2014). While some studies have concluded that "the economic benefits are the main reason" to host these events (Malfas, Theodoraki, \& Houlihan, 2004, p. 218), others have argued that the positive social impacts, such as community pride and international recognition, are seen as more important by residents of host communities (Gursoy et al., 2011; Prayag et al., 2013).

As suggested by the State Department of Tourism (Secretaria Estadual de Turismo - SET), residents who believe that hosting a mega-event can have positive impacts on their community and/or their well-being will consequently support the idea of hosting a mega-event in their community. Therefore, it is imperative that the public policies directed towards staging mega-events and their planning take into account the social return that these events can bring to the population, mainly because it is the people who experience most of the direct impacts-before, during, and after the event-of construction projects, adaptation of the city, and positive and negative legacies. Countries such as Brazil, with deficiencies in areas such as health and education, must justify the greater investments in non-priority infrastructure to the population, taking into account the benefits that these investments can bring in terms of job generation, the tourism economy, and more leisure and culture options, as indicated by Rossi (2013).

Hypothesis 8: Residents tend to be in favour of staging the Olympic Games.

Hypothesis 9: Residents are resistant to tourists arriving in the city.

Hypothesis 10: Mega-events generate innovation for the host destination. 


\section{METHODOLOGY}

A face-to-face quantitative survey was conducted over three years, during three periods (before, during, and after the event), with a total of 1,211 interviewees in the city of Rio de Janeiro, Brazil. The methodology of the research is detailed next.

\section{a. Objective}

The objective of the present study was to analyse the residents' perceptions of the Olympic Games in the city of Rio de Janeiro, for the three periods of the event: before, during, and after hosting the sporting megaevent. Based on the literature, we sought to:

(1) Identify the general support of the residents for the Games and whether there was a change in their perceptions during the different periods; and

(2) Evaluate residents' perceptions about possible negative and positive impacts of the mega-event, such as economic gains, price increases, business activity, financial losses, job generation, tourist activity, visibility, urban mobility, airport infrastructure, public safety, destination's reputation, sporting interest, and the image of the host city.

The variables that were used to measure the perceptions of mega-event impacts and support for mega-events were defined after an extensive review of the literature, inspired in particular by the impacts defined by Allen (2008), as well as Prayag et al. (2013), Gursoy and Kendall (2006), and Kim et al. (2006). According to Allen et al. (2008), the positive and negative impacts are divided as follows: social and cultural; physical and environmental; political, and tourism and economic (Table 1).

Table 1. Positive and negative impacts of mega-events

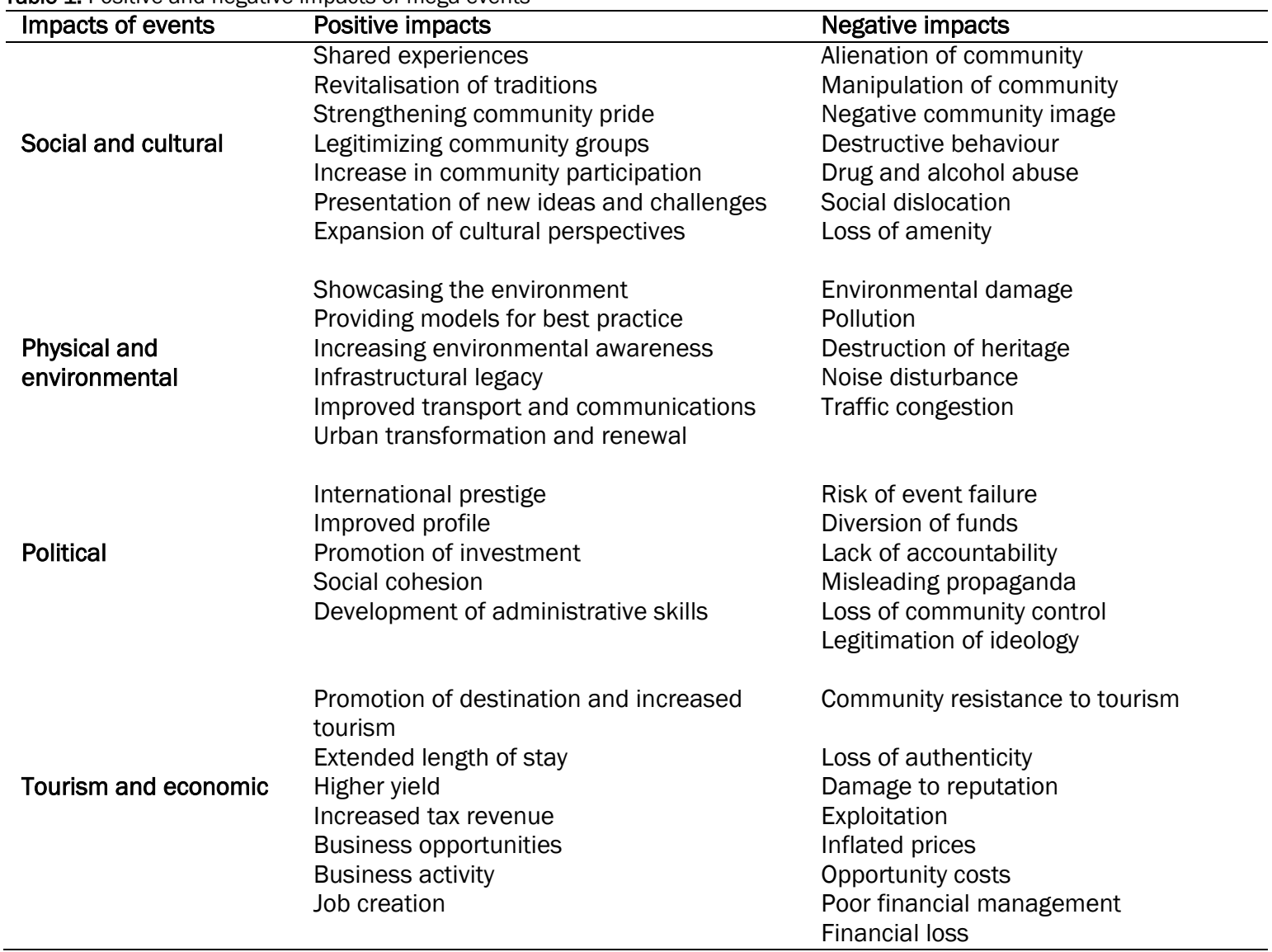

Source: Allen et al. (2008)

\section{b. Sample and research method}


To achieve the study objective, a face-to-face quantitative survey was conducted with residents of the city of Rio de Janeiro, at three distinct times: one year before the Olympics (August 3 to 28, 2015), totalling 426 valid responses; during the Olympics (August 15 to 25, 2016), totalling 391 valid responses; and one year after the event (August 15 to 30,2017), totalling 394 valid questionnaires. The data collection instruments were applied in four specific regions of the city: Centro, Zona Sul, Barra da Tijuca, and Deodoro-the main areas impacted by the Rio 2016 Olympic Games. The respondents were randomly selected at these locations, and the sample size was calculated based on a confidence level of $95 \%$ and an error margin of $5 \%$ (Bolfarine \& Bussab, 2005).

\section{c. Research instrument and measures}

The construction of the survey instrument was based on the model proposed by Allen et al. (2008). The positive impacts of mega-events included the promotion of the destination, increased tourism, extended tourist length of stay, profitability for the sector, increased income tax revenue, business opportunities, business activity, and the generation of jobs for the event. In turn, the negative impacts included the community's resistance to tourism, loss of authenticity and damage to the destination's reputation, exploitation, inflated prices, opportunity costs, financial mismanagement, financial losses, etc. The data collection instrument included three main components:

(1) The first section of the questionnaire included questions about the respondents' demographic information, such as area of residence and involvement with the Games.

(2) In the second section, the residents answered questions about their interest in the World Cup and the Olympics; for example, if it was a good choice for Rio de Janeiro to host the mega-event, and if the Games were having an impact on their neighbourhood and on their routine.

(3) The third section included questions, answered on a Likert scale, regarding business activity and economic gains, price increases due to the Olympics, financial loss, business opportunities, job creation, publicizing tourist activity, damage to reputation of the host city, increased number of tourists, and hidden problems of the country. There were also questions regarding the long-term legacy in relation to urban mobility, airport infrastructure, public safety, tourism, and sport. For these questions, a five-point Likert scale was used, as follows: 1 = totally disagree, 2 = partially disagree, $3=$ neither agree nor disagree, $4=$ partially agree, and $5=$ totally agree. There was another question in this section, in which the respondent evaluated whether safety was a factor that currently affects the image of the city of Rio de Janeiro. This question could be answered as follows: $-1=y e s$, it has a negative effect; $0=$ no, it does not have an effect; or $1=y e s$, it has a positive effect.

(4) Finally, the last section of the questionnaire contained profile data and open questions about the tangible and intangible aspects, in which the respondents were asked about their perception regarding the main positive and negative impacts of the Olympic Games. This was an open question, so the respondents answered spontaneously.

\section{d. Data analysis}

Data were analysed using the Statistical Package for the Social Sciences (SPSS) software. To test whether there was a difference in the perceptions of residents regarding the impacts of Olympic Games on the host city in the three different periods (before, during, and after the Olympics), analysis of variance (ANOVA) and binary logistic regression were performed.

ANOVA was used to investigate the perception of the residents before, during, and after the mega-event in the host city of the Rio 2016 Olympic Games. When ANOVA indicated a statistically significant difference, we used a post hoc test (the Duncan's multiple range test) in order to determine the difference across the three Olympic time periods. The ANOVA technique was performed for the following variables: business activity and economic gains; price increases due to the Olympics; financial loss; business opportunities; jobs created; publicity of tourist activity; reputation of the host city; increased number of tourists; hiding problems of the 
country; long-term legacy in relation to urban mobility, airport infrastructure, public safety, tourism and sport; and finally, the image of the host city. The results are shown in Tables 4, 5, 8, and 9.

To compare the periods (before/during/after), when the response variable was binary (yes/no), we performed the binary logistic regression, where the independent variable was the periods transformed into dummy variables, with the 'pre-Olympic' period set as the reference category. The response variable was the question about the impact (on the resident's neighbourhood and on the resident's routine) and the question about choosing Rio as the Olympic city. The results are presented on Tables 3, 6, and 7.

\section{RESULTS}

Table 2 details the sociodemographic profile of the population interviewed. Based on the data, over the three periods, the population interviewed was well divided between men and women, and most respondents were young. The education level of most of the residents was up to university level, with a family income of up to $\mathrm{R} \$ 7,240$.

Table 2 - Demographic profile of the respondents

\begin{tabular}{|c|c|c|c|c|c|c|c|c|}
\hline \multirow[t]{2}{*}{ Variables } & \multicolumn{2}{|c|}{$\begin{array}{l}\text { Before }(\mathrm{N}= \\
426)\end{array}$} & \multicolumn{2}{|c|}{$\begin{array}{l}\text { During }(\mathrm{N}= \\
391)\end{array}$} & \multicolumn{2}{|c|}{ After $(\mathrm{N}=394)$} & \multicolumn{2}{|l|}{ Total } \\
\hline & Freq. & $\begin{array}{l}\text { Percent } \\
(\%)\end{array}$ & Freq. & $\begin{array}{l}\text { Percent } \\
(\%)\end{array}$ & Freq. & $\begin{array}{l}\text { Percent } \\
(\%)\end{array}$ & Freq. & $\begin{array}{l}\text { Per- } \\
\text { cent } \\
\text { (\%) }\end{array}$ \\
\hline \multicolumn{9}{|l|}{ Gender } \\
\hline Male & 182 & 42.7 & 164 & 41.9 & 187 & 47.5 & 533 & 44.0 \\
\hline Female & 244 & 57.3 & 227 & 58.1 & 207 & 52.5 & 678 & 56.0 \\
\hline \multicolumn{9}{|l|}{ Age } \\
\hline $18-25$ years & 89 & 20.9 & 153 & 39.1 & 79 & 20.1 & 321 & 26.5 \\
\hline 26-35 years & 112 & 26.3 & 71 & 18.2 & 107 & 27.2 & 290 & 23.9 \\
\hline $36-45$ years & 72 & 16.9 & 67 & 17.1 & 83 & 21.1 & 222 & 18.3 \\
\hline $46-55$ years & 76 & 17.8 & 59 & 15.1 & 72 & 18.3 & 207 & 17.1 \\
\hline $56-64$ years & 37 & 8.7 & 28 & 7.2 & 35 & 8.9 & 100 & 8.3 \\
\hline 65 years and above & 40 & 9.4 & 13 & 3.3 & 18 & 4.6 & 71 & 5.9 \\
\hline \multicolumn{9}{|l|}{ Education level } \\
\hline Primary or below & 24 & 6 & 23 & 6 & 11 & 3 & 58 & 5 \\
\hline Secondary & 104 & 24 & 113 & 29 & 100 & 25 & 317 & 26 \\
\hline University & 244 & 57 & 200 & 51 & 210 & 53 & 654 & 54 \\
\hline Postgraduate & 54 & 13 & 55 & 14 & 73 & 19 & 182 & 15 \\
\hline \multicolumn{9}{|l|}{$\begin{array}{l}\text { Monthly household } \\
\text { income }\end{array}$} \\
\hline Below R\$ 725 & 25 & 5.9 & 6 & 1.5 & 6 & 1.5 & 37 & 3.1 \\
\hline $\mathrm{R} \$ 725-1,448$ & 29 & 6.8 & 40 & 10.2 & 28 & 7.1 & 97 & 8.0 \\
\hline $\mathrm{R} \$ 1,449-2,172$ & 68 & 16.0 & 51 & 13.0 & 35 & 8.9 & 154 & 12.7 \\
\hline $\mathrm{R} \$ 2,173-3,620$ & 90 & 21.1 & 83 & 21.2 & 96 & 24.4 & 269 & 22.2 \\
\hline $\mathrm{R} \$ 3,621-7,240$ & 105 & 24.6 & 66 & 16.9 & 88 & 22.3 & 259 & 21.4 \\
\hline $\mathrm{R} \$ 7,241-14,480$ & 56 & 13.1 & 67 & 17.1 & 69 & 17.5 & 192 & 15.9 \\
\hline $\mathrm{R} \$ 14,481$ or higher & 17 & 4.0 & 24 & 6.1 & 26 & 6.6 & 67 & 5.5 \\
\hline $\begin{array}{l}\text { Don't know/don't } \\
\text { want to declare }\end{array}$ & 36 & 8.5 & 54 & 13.8 & 46 & 11.7 & 136 & 11.2 \\
\hline
\end{tabular}

\section{a. Comparison of residents' perceptions}

In regard to the question "Was it a good choice for the city of Rio de Janeiro to host the 2016 Olympic Games?", there was no difference in the residents' opinions among the three periods (before/during/after) ( $p$-values $>0.10$ in Table 2). This means that regardless of the period, the residents' opinions were the same. Before, during, and after the event, the population was very divided between those who thought it was a good choice and those who did not think it was a good choice to host the Olympic Games in the city of Rio de Janeiro. 
Table 3 - Was it a good choice for the city of Rio de Janeiro to host the 2016 Olympic Games? (Percentages and binary logistic regression results)

\begin{tabular}{lll|lc}
\hline & $\begin{array}{l}\text { Yes } \\
\text { (percent valid) }\end{array}$ & $\begin{array}{l}\text { No } \\
\text { (percent valid) }\end{array}$ & $\begin{array}{l}\text { p-value } \\
\text { (binary logistic regression) }\end{array}$ & EXP(B) \\
\hline Before & 54.5 & 45.5 & $(\mathrm{a})$ & $(\mathrm{a})$ \\
During & 59.3 & 40.7 & 0.160 & 1.220 \\
After & 54.3 & 45.7 & 0.967 & 0.994 \\
\hline
\end{tabular}

Note: (a) The 'Before' category is the reference category

In regard to the question "How much do you consider yourself to be interested in the World Cup?" during and after the Olympics, the residents had a significantly higher motivation than in the pre-Olympic period $(p<.01)$. The same occurred for the question "How much do you consider yourself to be interested in the Olympic Games?", which shows the influence of staging the sporting mega-event in a destination and the increase in interest in the event itself and in the theme-in this case, sport.

Table 4 - ANOVA and post hoc test results for the three different Olympics periods (before/during/after): Perception of the host city's issues

\begin{tabular}{|c|c|c|c|c|c|c|c|}
\hline \multirow[t]{2}{*}{ Questions and attributes } & \multicolumn{2}{|l|}{ Before } & \multicolumn{2}{|c|}{ During } & \multicolumn{2}{|l|}{ After } & \multirow{2}{*}{$\begin{array}{l}\text { ANOVA } \\
\text { F-test }\end{array}$} \\
\hline & Mean & SD & Mean & SD & Mean & SD & \\
\hline $\begin{array}{l}\text { How much do you consider yourself to be } \\
\text { interested in the World Cup? }\end{array}$ & $\underline{5.94}$ & 3.13 & 6.77 & 2.43 & 6.73 & 2.47 & $12.067 * * *$ \\
\hline $\begin{array}{l}\text { How much do you consider yourself to be } \\
\text { interested in the Olympic Games? }\end{array}$ & $\underline{6.53}$ & 2.87 & 7.42 & 2.33 & 7.43 & 2.10 & $18.046 * * *$ \\
\hline
\end{tabular}

Note: The items were assessed on a 0 to 10 scale.

$* p<.05, * * p<.01, * * * p<.001$

Duncan's multiple range test was performed. The group mean that was significantly different from the others is underlined.

It was surprising to observe that the degree of interest of the interviewed residents in sport increased only during the Olympic Games-before and after the event, the perception remained the same. In any case, the data indicate that the interest in sporting events is relatively high.

Table 5 - Descriptive statistics, ANOVA and post hoc test results for the three different Olympics periods (before/during/after): Degree of interest in sport

\begin{tabular}{lccccc}
\hline & $\begin{array}{c}\text { Decreased } \\
\text { (percent } \\
\text { valid) }\end{array}$ & $\begin{array}{c}\text { Remained the } \\
\text { same } \\
\text { (percent valid) }\end{array}$ & $\begin{array}{c}\text { Increased } \\
\text { (percent } \\
\text { valid) }\end{array}$ & Mean (SD) & $\begin{array}{c}\text { ANOVA } \\
\text { F-test }\end{array}$ \\
\hline Before & 7.0 & 71.8 & 21.1 & $0.14(0.51)$ & $18.046 * * *$ \\
During & 5.1 & 55.2 & 39.6 & $\underline{0.34}(0.57)$ & $0.18(0.43)$ \\
After & 2.0 & 78.4 & 19.9 & & \\
\hline
\end{tabular}

Note: The items were assessed according to the following scale: decreased $=-1$; remained the same $=0$; increased $=1$. $* p<.05, * * p<.01, * * * p<.001$.

Duncan's multiple range test was performed. The group mean that was significantly different from the others is underlined.

Regarding the impact on the neighbourhood, the residents' opinions during the games were not significantly different from the opinions before them (they agreed in the same proportion) ( $p$-values $>.10$ ); but after the Olympics, the opinions changed (the proportion of 'yes' answers was significantly lower). The same occurred with the impact on the routine ( $p$-values $<.01)$.

Regarding the impact of choosing Rio for the Olympics, the opinions during and post the Olympics were not significantly different from the opinions before ( $p$-values $>.10$ ). The results are presented in Table 6 and Table 7.

Table 6 - Did the 2016 Olympics have an impact on the neighbourhood where you live? (Percentages and binary logistic regression results)

\begin{tabular}{lllll}
\hline & $\begin{array}{l}\text { Yes } \\
\text { (percent valid) }\end{array}$ & $\begin{array}{l}\text { No } \\
\text { (percent valid) }\end{array}$ & $\begin{array}{l}\text { p-value } \\
\text { (binary logistic regression) }\end{array}$ & EXP(B) \\
\hline Before & 38.3 & 61.7 & $($ a) & $(\mathrm{a})$ \\
During & 34.5 & 65.5 & 0.268 & 0.851 \\
After & 22.3 & 77.7 & $0.000 * * *$ & 0.464 \\
\hline
\end{tabular}

Note: (a) The 'Before' category is the reference category.

$* p<.05 . * * p<.01 . * * * p<.001$ 
Table 7 - Did the 2016 Olympic Games have an impact on your routine? (Percentages and binary logistic regressionresults)

\begin{tabular}{lcccc}
\hline & $\begin{array}{c}\text { Yes } \\
\text { (percent valid) }\end{array}$ & $\begin{array}{c}\text { No } \\
\text { (percent valid) }\end{array}$ & $\begin{array}{c}\text { p-value } \\
\text { (binary logistic regression) }\end{array}$ & EXP(B) \\
\hline Before & 53.3 & 46.7 & $(a)$ & $($ a) \\
During & 54.0 & 46.0 & 0.846 & 1.028 \\
After & 33.0 & 67.0 & $0.000 * * *$ & 0.432 \\
\hline Note: (a) The ‘Before' category is the reference categry & &
\end{tabular}

Note: (a) The 'Before' category is the reference category.

$* \mathrm{p}<.05 . * * \mathrm{p}<.01 . * * * \mathrm{p}<.001$.

\section{b. Impacts perceived by the resident population}

In relation to the impacts of the Olympic Games on the host city, we obtained the following findings: regarding the sentence "The Olympic Games damage the reputation of the host city?", the perception of the residents did not change over the different time periods, and believed that, in general, the mega-event did not damage the image of the city of Rio de Janeiro. On the contrary, the image of the destination strengthened. Regarding the resistance of the population to the tourists arriving for the Olympic Games, the respondents believe that this is not such a relevant aspect, with this perception of resistance being greater during and after the event. Nonetheless, a minority of respondents saw this as a problem.

The data indicated that the promotion of tourist activity and of destination as well as the increase in tourists at the host destination are perceived more before and during the event. At these times-and especially during the event-there is a lot of exposure of the destination brand, promoting the attractions and the event itself in national and international media. As a result of the event, more tourists come to the destination. Once the event is over, this flow of tourists decreases, and it is natural for the perception of the increase in tourists to the destination to decrease.

It is suggested that future studies analyse how much the Olympic Games were able to attract new demand and make a certain flow of people return to the destination. The results of a study conducted with national and international tourists during the Olympic Games (Zouain Lohmann, Virkki, \& Bezerra, 2018) revealed that for $64.7 \%$ of the foreign respondents, the trip to participate in the Rio 2016 Olympic Games was their first visit to the country, and for $73.9 \%$ of them, it was also their first visit to the host city. In turn, for a large number of Brazilian tourists (75.9\%), the Olympic Games was a chance to return to Rio de Janeiro, while for a smaller number (24.1\%) it was a chance to visit the city for the first time. For both domestic and international tourists it was a great opportunity to participate in the Olympic Games-79.9 and $57.1 \%$, respectively, were experiencing the event for the first time. The results of the study also showed that a large percentage of respondents visited tourist attractions in Rio $(94.7 \%$ for international tourists and $77.7 \%$ for domestic tourists). Almost half of the foreigners (48.2\%) took the opportunity to visit other destinations near the host city, while $23.8 \%$ of the domestic tourists did so. These data reinforce the potential of mega-events for attracting tourists to the destination.

Regarding the statement "The Olympic Games generates gains for the host city", it was found that the perception of the residents as to the Olympic Games stimulating business activity in the host city and generating business opportunities and jobs were very similar, as these aspects were perceived more before and during the Games. In the post-Olympic period this perception diminished, which can be explained by the fact that many jobs and business opportunities end after staging the event. An example of this is the construction of urban infrastructure, in which the jobs decrease considerably, given that the construction for the event is finished. Another example is the business generated to satisfy the demand from the Games and the flow of people generated by the mega-event; once the event ends, the demand also decreases, and consequently, the business opportunities and extra income decrease.

As for lasting improvements, there were differences in the residents' opinions considering the three periods (before/during/after) $(p>$.05). Regarding the urban mobility aspect, the residents' perceptions improved from the period before the event to the time when the Games were staged and after the Games. Regarding 
tourism, safety, and sport, the perception of the residents also changed with the different periods of the event-during the event, the perception of these legacies was greater than in the period before and after the event. This result is explained in part by increased investment in safety specifically for the event, and a greater flow of tourists and investment in sport during the period of the Olympic Games in the city of Rio de Janeiro. As for airport infrastructure, the perception during and after the event was greater than before the event. This result is partly due to the fact that construction was completed during and sometimes even after the event.

Regarding the negative impacts, before and during the event the residents understood that due to the Olympic Games, there was a significant increase in prices. After the Olympics, there was a greater perception of the financial liability generated in the city of Rio de Janeiro. It is worth noting that the residents perceive safety as a factor that adversely affects the image of Rio de Janeiro, and this variable was perceived more negatively in the post-Olympic period.

Table 8 - ANOVA F-test for questions and attributes of Olympic Games completion in the city

\begin{tabular}{|c|c|c|c|c|c|c|c|}
\hline \multirow[t]{2}{*}{ Questions and attributes } & \multicolumn{2}{|l|}{ Before } & \multicolumn{2}{|c|}{ During } & \multicolumn{2}{|l|}{ After } & \multirow{2}{*}{$\begin{array}{l}\text { ANOVA } \\
\text { F-test }\end{array}$} \\
\hline & Mean & SD & Mean & SD & Mean & SD & \\
\hline $\begin{array}{l}\text { The Olympic Games generates economic gains for the } \\
\text { city of Rio de Janeiro. }\end{array}$ & 4.30 & 1.22 & 4.28 & 1.06 & 2.90 & 1.42 & $164.450 * * *$ \\
\hline $\begin{array}{l}\text { There is an increase in prices due to the Olympic } \\
\text { Games. }\end{array}$ & 4.52 & 1.13 & 4.51 & 1.06 & $\underline{3.15}$ & 1.43 & $167.870 * * *$ \\
\hline $\begin{array}{l}\text { The Olympic Games stimulates business activity in } \\
\text { the host city. }\end{array}$ & 4.60 & 1.00 & 4.60 & .74 & $\underline{3.04}$ & 1.42 & $273.413 * * *$ \\
\hline There is financial liability for the host city. & 3.20 & 1.76 & 3.16 & 1.56 & $\underline{4.15}$ & 1.19 & $53.899 * * *$ \\
\hline $\begin{array}{l}\text { The Olympic Games provides business opportunities } \\
\text { for the host city. }\end{array}$ & 4.45 & 1.16 & 4.42 & .90 & 3.14 & 1.41 & $160.259 * * *$ \\
\hline The Olympic Games generates jobs in the host city. & 4.28 & 1.22 & 4.34 & 1.04 & $\underline{2.56}$ & 1.45 & $258.224 * * *$ \\
\hline $\begin{array}{l}\text { The Olympic Games promote the tourist activities of } \\
\text { the host city. }\end{array}$ & 4.73 & .84 & 4.78 & .59 & 3.23 & 1.32 & $334.429 * * *$ \\
\hline $\begin{array}{l}\text { The Olympic Games damage the reputation of the } \\
\text { host city. }\end{array}$ & $\underline{2.60}$ & 1.69 & $\underline{2.38}$ & 1.44 & $\underline{3.21}$ & 1.50 & $30.101 * * *$ \\
\hline $\begin{array}{l}\text { There will be resistance from the population towards } \\
\text { tourists arriving for the Olympic Games. }\end{array}$ & 1.68 & 1.30 & 2.06 & 1.47 & 1.90 & 1.19 & $8.761 * * *$ \\
\hline $\begin{array}{l}\text { The Olympic Games increase the number of tourists } \\
\text { coming to the host city. }\end{array}$ & 4.88 & .55 & 4.94 & .26 & $\underline{3.33}$ & 1.28 & $503.796 * * *$ \\
\hline Urban mobility & $\underline{3.24}$ & 1.74 & $\underline{3.60}$ & 1.46 & $\underline{4.04}$ & 1.30 & $28.238 * * *$ \\
\hline Airport infrastructure & $\underline{3.24}$ & 1.73 & 3.73 & 1.24 & 3.78 & 1.27 & $17.515 * * *$ \\
\hline Public safety & 1.99 & 1.44 & $\underline{2.52}$ & 1.59 & 1.37 & .81 & $74.311 * * *$ \\
\hline Tourism & $\underline{4.02}$ & 1.49 & 4.34 & 1.03 & $\underline{3.33}$ & 1.27 & $63.867 * * *$ \\
\hline Sport & 3.77 & 1.60 & 4.06 & 1.23 & $\underline{3.06}$ & 1.33 & $53.515 * * *$ \\
\hline
\end{tabular}

Table 9 - Descriptive statistics, ANOVA and post hoc test results for the three different periods of the Olympics (before/during/after): Perception of safety as a legacy

\begin{tabular}{llllll}
\hline & $\begin{array}{l}\text { Yes, in a } \\
\text { negative way } \\
\text { (percent } \\
\text { valid) }\end{array}$ & $\begin{array}{l}\text { Does not influ- } \\
\text { ence } \\
\text { (percent valid) }\end{array}$ & $\begin{array}{l}\text { Yes, in a pos- } \\
\text { itive way } \\
\text { (percent } \\
\text { valid) }\end{array}$ & Mean (SD) & $\begin{array}{l}\text { ANOVA } \\
\text { F-test }\end{array}$ \\
\hline Before & 87.6 & 5.9 & 6.6 & $-0.81(0.53)$ & $17.449 * * *$ \\
During & 86.4 & 4.3 & 9.2 & $-0.77(0.60)$ & \\
After & 97.5 & 1.5 & 1.0 & -0.96 $(0.23)$ & \\
\hline
\end{tabular}

Note: The items were assessed on the following scale: Yes, in a negative way = -1; Does not influence = 0; Yes, in a positive way = 1.

$* \mathrm{p}<.05, * * \mathrm{p}<.01, * * * \mathrm{p}<.001$.

Duncan's multiple range test was performed. The group mean that is significantly different from the others is underlined. 


\section{DISCUSSION AND CONCLUSIONS}

The present study determined, via an empirical survey of residents, the positive and negative impacts on the host destination that are generated by staging a mega-event. The case study was associated with the Olympic Games in the city of Rio de Janeiro, covering three important phases of the event (before, during, and after) over an interval of three years. These data contribute to academia, given that there are few longitudinal studies on residents from host cities of sporting mega-events in developing countries.

It was observed that over time, residents' perceptions of the legacies of mega-events change and are not always perceived as long-term; some are perceived very specifically during the event, as was the case of safety, which, in the view of the residents, improved greatly during the Olympic Games; however, as soon as the event ended, the perception also diminished. This is, in itself, an aspect that negatively impacts the image of the city of Rio de Janeiro, especially in the post-Olympic period. The survey data indicated that for $97.2 \%$ of the residents interviewed, safety worsened one year after the Games.

Urban mobility was the aspect in which the residents perceived improvement for the three different periods of the event, even though the construction projects affected their routine, especially before the event but also during the staging of the Games. According to Lindau, Petzhold, Tavares, and Facchini, 2016, the Olympic Games are the largest sporting event in the world and the most complex in terms of infrastructure, logistics, and operations. The improvement in transport was the most important delivery of the Rio 2016 Olympic Games, enabling greater use of urban transport by residents. Moreover, the lessons learned from transport structures in previous mega-events was also of great value in generating accumulated knowledge that enabled innovation in this area.

During the event, some positive perceptions greatly improved, particularly in the areas of: increased tourism, visibility of the destination, infrastructure improvements, and interest in sport. However, the high costs and the inconveniences associated with corruption and poor use of public investment were critical aspects, which is consistent with the study of Karadakis, Kaplanidou, and Karlis (2016). These aspects left much of the interviewed residents in doubt about it having been a good choice to host the Olympic Games in the city of Rio de Janeiro.

According to Rocha and Fink (2017), the brand image of the Olympic Games seems to be strong enough to guarantee positive attitudes towards the event and consequently to attract people to the event (Ajzen, 2001; Uysal \& Jurowski, 1994), with no interaction with the host country being necessary. However, in the case of Brazil, corruption schemes have been negative points that, in addition to the destination's image, have affected the Olympic Committee itself.

As suggested by Müller (2017), this conflict between positive and negative impacts is a paradox of the megaevent. Managers in different government institutions should take care so that the negative effects do not compromise the positive effects, potentially squandering the legacy of the mega-event. As this study evaluated the residents' perceptions at three different times (before, during, and after the mega-event), there is a need for evaluations of these perceptions in future editions of the Olympic Games. According to Sharma, Dyer, Carter, and Gursoy (2008), the success of hosting a sporting mega-event depends on the support of local residents, hence the importance of investigating their perceptions and trying to include them in the process, from the candidature to the staging and finalization of the Games.

Although Rio de Janeiro faces many challenges in the short, medium, and long term, there is still a window of opportunity for the city's stakeholders to take advantage of a positive legacy for the residents of Rio and ensure their continued support for future events. The organization of a mega-event is somewhat complex, given the number of stakeholders that must be involved in the process, whether at the local, regional, national, or international level.

The success of the event is directly related to the environment that is created for interaction between the different stakeholders of the society. Through these data, it is expected that the lessons learned from the Rio 2016 Olympic Games will serve as a broader reflection of the possible positive and negative effects of sporting mega-events. It is also desirable that future host destinations create an environment favourable to innovation, bringing academia, government, and the market closer together. 


\section{a. Practical implications}

For future editions of the Olympic Games, it is suggested that residents and universities be increasingly included in the process before, during, and after the sporting mega-event so that negative effects are mitigated and positive effects maximized and so that it is also possible to create an environment for innovation, as proposed by the quadruple helix model.

\section{b. Limitations}

The study was limited to the specific case of the Olympic Games in the city of Rio de Janeiro and to the perception of residents of the city. Thus, it cannot be claimed that the same effects will be perceived in future editions of the event in other host destinations or in future editions of sporting mega-events in the city of Rio de Janeiro, given that they are different times and diverse cultural and socioeconomic contexts.

The tangible and intangible impacts were also not analysed separately. Karadakis, Kaplanidou, and Karlis (2016) state that more studies need to be conducted to examine which dominant intangible legacies are present in the minds of consumers of the Olympic Games and examine differences in framing the legacy question for Olympic Games in general and for the Summer Games or Winter Games. Finally, future research should examine the legacy perception using longitudinal data.

\section{c. Post-Games follow-up research}

It is suggested that the same research be conducted in future editions of both the Olympic Games and the World Cup, in order to understand the different contexts. For future studies, long-term monitoring is suggested, given that many of the effects from mega-events are medium and long term. Moreover, it is suggested that forthcoming studies make an effort to broaden the range of stakeholders interviewed, including not only residents and tourists (representatives of civil society) but also universities and the public and private sector, who are the stakeholders who through greater interaction can more easily favour territorial innovation in a destination. This would make it possible to analyse more in-depth the effects, opportunities, and risks associated with mega-events and to identify strategies to mitigate the negative effects, identify new opportunities, and maximize the positive effects in the different periods of the event.

\section{d. Acknowledgement}

We would like to thank FAPERJ - Foundation for Research Support of the State of Rio de Janeiro for help and support of our studies.

\section{REFERENCES}

Al-Emadi, A., Kaplanidou, K., Diop, A., Sagas, M., Le, K.T. \& Mustafa, S. A.-A. (2016). 2022 Qatar World Cup: Impact Perceptions among Qatar Residents. Journal of Travel Research, 56(5), 1-17. DOI: https://doi.org/10.1177/0047287516652502

Andranovich, G., Burbank, J., \& Heying, C. (2001). Olympic Cities: Lessons learned from Mega-Event Politics. Journal of Urban Affairs, 23(2), 113-131. DOI: https://doi.org/10.1111/0735-2166.00079

Balduck, A.L.,Maes, M., \& Buelens, M. (2011). The social impact of the Tour de France: Comparisons of residents' pre- and post-event perceptions. European Sport Management Quarterly, 11(2), 91-113. DOI: https://doi.org/10.1080/16184742.2011.559134

Brian, S. E., \& Anders, S. (2002) The Cambridge dictionary of statistics. Cambridge: Cambridge.

Bovy, P. H. (2009). Mega event transport planning and mobility management. Sport Event Management \& Organisation Seminar (SEMOS), Lausanne, February 2009.

Bull, C., \& Lovell, J. (2007). The impact of hosting major sporting events on local residents: an analysis of the views and perceptions of Canterbury residents in relation to the Tour de France 2007. Journal of Sport \& Tourism, 12(3e4), 229-248. DOI: http://dx.doi.org/10.1080/14775080701736973. 
Capel, H. (2010). Los Juegos Olímpicos, entre el urbanismo, el marketing y lós consensos sociales. Biblio $3 W$. Revista Bibliográfica de Geografia y Ciencias Sociales, 15(895).

Carayannis, E. G., \& Campbell, D. F. (2014). Developed democracies versus emerging autocracies: arts, democracy, and innovation in Quadruple Helix innovation systems. Journal of Innovation and Entrepreneurship, 3(1), 12. DOI: https://doi.org/10.1186/s13731-014-0012-2

Carey, M., Mason, D. S. \& Misener, L. (2011). Social Responsibility and The Competitive Bid Process for Major Sporting Events. Journal of Sports and Social Issues, 35(3), 246-263. DOI: https://doi.org/10.1177/0193723511416985

Chalip, L., \& Costa, C. A. (2005). Sport event tourism and the destination brand: Towards a general theory. Sport in Society, 8(2), 218-237. DOI: https://doi.org/10.1080/17430430500108579

Chappelet, J. L. (2008). Olympic Environmental Concerns as a Legacy of the Winter Games. The International Journal of the History of Sport, 15(14), 1884-1902. DOI: https://doi.org/10.1080/09523360802438991

Chen, F. (2010). Study on the longitudinal changes of urban residents' perceptions and attitude towards mega-events: a Case Study of Qingdao Hosting the 2008 Olympic Sailing Regatta. Tourism Tribune, 25(10), 77-84. In Chinese.

Chen, F., \& Tian, L. (2015). Comparative study on residents' perceptions of follow-up impacts of the 2008 Olympics. Tourism Management, 51, 263-281. DOI: https://dx.doi.org./10.1016/j.tourman.2015.05.029

Cho, J.-H., \& Bairner, A. (2012). The sociocultural legacy of the 1988 Seoul Olympic Games. Leisure Studies, 31, 271-289. DOI: https://doi.org/10.1080/02614367.2011.636178

Chou, M.C. (2013). Does tourism development promote economic grow thin transition countries? A panel data analysis. Economic Modelling, 33(1), 226-232. http://dx.doi.org/10.1016/j.econmod.2013.04.024

Dansero, E., \& Puttilli, M. (2010). Mega-events tourism legacies: The case of the Torino 2006 Winter Olympic Games - A territorialisation approach. Leisure Studies, 29, 321-341. DOI: https://doi.org/10.1080/02614361003716966

Davies, L. E. (2012). Beyond the Games: Regeneration legacies and London 2012. Leisure Studies, 31, 309337. DOI: https://doi.org/10.1080/02614367.2011.649779

Deccio, C., \& Baloglu, S. (2002). Nonhost community resident reactions to the 2002 Winter Olympics: the spillover impacts. Journal of Travel Research, 41(1), 46-56. DOI: http://dx.doi.org/10.1177/0047287502041001006

Montgomery, D. C. (1991). Design and analysis of experiments. New York: John Wiley \& Sons.

Dwyer, L., Forsyth, P., \& Spurr, R. (2004). Evaluating tourism's economic effects: New and old approaches. Tourism Management, 25(3), 307-317. DOI: https://doi.org/10.1016/j.sbspro.2014.07.305

Essex, S., \& Chalkley, B. (1998). Olympic Games: catalyst of urban change. Leisure Studies, 17, $187-206$. DOI: https://doi.org/10.1080/026143698375123

Faulkner, B., \& Tideswell, C. (1997). A framework for monitoring community impacts of tourism. Journal of Sustainable Tourism, 5(1), 3-28. DOI: https://doi.org/10.1080/09669589708667273

Fourie, J.,\& Santana-Gallego, M. (2011). The impact of mega-sport events on tourist arrivals. Tourism Management, 32(6), 1364-1370. DOI: https://doi.org/10.1016/j.tourman.2011.01.011

Gelan, Ayele. (2003). Local Economic Impacts, the British Open. Annals of Tourism Research, 30(2), 406-25. DOI: https://doi.org/10.1016/S0160-7383(02)00098-1

Getz, D. (1997). Event Management \& Event Tourism. New York: Cognizant Communication Corporation.

Gibson, H. J., Walker, M., Thapa, B., Kaplanidou, K., Geldenhuys, S., \& Coetzee, W. (2014). Psychic income and social capital among host nation residents: A pre-post analysis of the 2010 FIFA World Cup in South Africa. Tourism Management, 44(3), 113-122. DOI: https://doi.org/10.1016/j.tourman.2013.12.013

Giesecke, J. \& Madden, J (2011) Modelling the economic impacts of the Sydney Olympics in retrospect Game over for the bonanza story? Economic Papers, 30(2), 218-232. DOI: https://doi.org/10.1111/j.17593441.2011.00109.x

Gratton, C. \& Preuss, H. (2008). Maximizing Olympic Impacts by Building Up Legacies. The International Journal of the History of Sport., 15(14), 1922-1938. DOI: https://doi.org/10.1080/09523360802439023 
Gratton, C., Shibli, S., \& Coleman, R. (2005). Sport and economic regeneration in cities. Urban Studies, 42(56), 985-999. DOI: https://doi.org/10.1080/00420980500107045

Gursoy, D., \& Kendall, K. W. (2006). Hosting megaevents-Modelling locals' support. Annals of Tourism Research, 33(3), 603-623. DOI: https://doi.org/10.1016/j.annals.2006.01.005

Gursoy, D., Chi, C. G., Ai, J., \& Chen, B. T. (2011). Temporal change in resident perceptions of a mega-event: the Beijing 2008 Olympic Games. Tourism Geographies, 13(2), 299-324. DOI: http://dx.doi.org/10.1080/14616688.2010.529935

Gursoy, D., Yolal, M., Ribeiro, M. A., \& Panosso Netto, A. (2016). Impact of Trust on Local Residents' MegaEvent perceptions and Their Support. Journal of Travel Research, 56(3), 393-406. DOI: https://doi.org/10.1177/0047287516643415

Haley, A. J., Snaith, T., \& Miller, G. (2005). Social impacts of tourism-A case study of Bath, UK. Annals of Tourism Research, 32(3), 647-668. DOI: https://doi.org/10.1016/j.annals.2004.10.009

Hennessey, S. M., Yun, D., MacDonald, R \& MacEachern, M. (2010). The effects of advertising awareness and media form on travel intentions. Journal of Hospitality Marketing \& Management, 19(3), 217-243. DOI: https://doi.org/10.1080/19368621003591335

Hiller, H. (1990) The urban transformation of a landmark event: the 1988 Calgary Winter Olympics. Urban Affairs Quarterly, 26(1), 118-137. DOl: https://doi.org/10.1177/004208169002600106

Hiller, H. (1995). Conventions as mega-events: A new model for convention -host city relationships. Tourism Management, 16(5), 375-379. DOI: https://doi.org/10.1016/0261-5177(95)00041-L

Hiller, H. (2006). Post-event Outcomes and the Post-modern Turn: The Olympics and Urban Transformations. European Sport Management Quarterly, 6(4), 317-332. DOI: https://doi.org/10.1080/16184740601154458

Horne, J. \& Manzenreiter, W. (2007). An introduction to the sociology of sports mega-events. The Social Review, 54(2), 1-24. DOI: https://doi.org/10.1111/j.1467-954X.2006.00650.x

Huang, H., \& Lou, S. (2010). Sport event industry development in China and abroad. Sports Science Research, 31(1), 18-22. DOI: https://doi.org/10.5367/te.2013.0340

Huang, H., \& Zhang, L. (2012). Estimation of the non-market value of sports events: A case study of the civic pride generated by the 2009 Shanghai ATP Masters 1000. Tourism Economics, 18(4), 887-895. DOI: https://doi.org/10.5367/te.2012.0139

Humphreys, B. R., \& Prokopowicz, S. (2007). Assessing the impact of sports mega-events in transition economies: Euro 2012 in Poland and Ukraine. International Journal of Sport Management and Marketing, 2(5), 496-509. DOI: https://doi.org/10.1504/IJSMM.2007.013963

Jeong, G. H., \& Faulkner, B. (1996). Resident perceptions of mega-event impacts: the Taejon International Exposition case. Festival Management and Event Tourism, 4(1e2), 3-11. DOI: http://dx.doi.org/10.3727/106527096792232388

Jones, C. (2001). Mega-events and host-region impacts: determining the true worth of the 1999 Rugby World Cup. International Journal of Tourism Research, 3, 241-251. DOI: https://doi.org/10.1002/jtr.326

Jurowski, C., \& Gursoy, D. (2004). Distance effects on residents' attitudes toward tourism. Annals of Tourism Research, 31(2), 296-312. DOI: http://dx.doi.org/10.1016/j.annals.2003.12.005

Kaplanidou, K. (2012). The importance of legacy outcomes for Olympic Games four summer host cities residents' quality of life: 1996-2008. European Sport Management Quarterly, 12(4), 397-433. DOI: https://doi.org/10.1080/16184742.2012.693118

Kaplanidou, G. K. \& Karadakis, K. (2010). Understanding the legacies of a host Olympic City: the case of the 2010 Vancouver Olympic Games. Sport Marketing Quarterly, 19, 110-117. DOI: http://dx.doi.org/10.1080/16184742.2012.680067

Kaplanidou, K., Karadakis, K., Gibson, H., Thapa, B., Walker, M., \& Geldenhuys, S., (2013). Quality of life, event impacts, and mega-event support among South African residents before and after the 2010 FIFA world cup. Journal of Travel Research, 52(5), 631-645. DOI: https://doi.org/10.1177/0047287513478501

Karadakis, K. \& Kaplanidou, G. K. (2010) Event leveraging of mega sport events: a SWOT analysis approach. International Journal of Event and Festival Management, 1(3), 170-185. DOI: http://dx.doi.org/10.1016/j.tourman.2015.03.007 
Karadakis, K., \& Kaplanidou, K. (2012). Legacy perceptions among host and non-host Olympic Games residents: A longitudinal study of the 2010 Vancouver Olympic Games. European Sport Management Quarterly, 12(3), 243-264. DOI: https://doi.org/10.1080/16184742.2012.680067

Karadakis, K., Kaplanidou, K., \& Karlis, G. (2016). Host and non-host resident awareness and perceptions of legacies for the 2010 Vancouver Winter Olympic Games. Loisir et Societe, 39(2), 195-209. DOI: https://doi.org/10.1080/07053436.2016.1198594

Kim, H. J., Gursoy, D., \& Lee, S.-B. (2006). The impact of the 2002 world cup on South Korea: comparisons of pre- and post-games. Tourism Management, 27(1), 86-96. DOl: http://dx.doi.org/10.1016/j.tourman.2004.07.010.

Kim, S. S., \& Petrick, J. F. (2005). Residents' perceptions on impacts of the FIFA 2002 World Cup: The case of Seoul as a host city. Tourism Management, 26(1), 25-38.DOI: http://dx.doi.org/10.1016/j.tour$\underline{\text { man.2003.09.013 }}$

Kim, S., \& Jun, J. (2016). The impact of event advertising on attitudes and visit intentions. Journal of Hospitality and Tourism Management, 29, 1-8. DOI: http://dx.doi.org/10.1016/i.jhtm.2016.04.002

Lindau, L. A., Petzhold, G., Tavares, V. B., \& Facchini, D. (2016). Mega events and the transformation of Rio de Janeiro into a mass-transit city. Research in Transportation Economics, 59, 196-203. https://doi.org/10.1016/j.retrec.2016.07.024

Lohmann, P. B. (2010). Megaeventos esportivos: impactos no turismo das cidades sedes. Dissertação, 133 f. Mestrado em Gestão Empresarial, Fundação Getúlio Vargas, Rio de Janeiro.

Lorde, T., Greenidge, D., \& Devonish, D. (2011). Local residents' perceptions of the impacts of the ICC Cricket World Cup 2007 on Barbados: comparisons of pre and post-games. Tourism Management, 32(2), 349-356. DOI: http://dx.doi.org/10.1016/j.tourman.2010.03.004.

Malfas, M., Theodoraki, E., \& Houlihan, B. (2004). Impacts of the Olympic Games as mega-events. Municipal Engineer, 157(3), 209-220. DOI: https://doi.org/10.1680/muen.2004.157.3.209

Mangan, J. A. (2008). Prologue: Guarantees of Global Goodwill: Post-Olympic Legacies - Too Many Limping White Elephants? The International Journal of the History of Sport, 25(14), 1869-1883 DOI: https://doi.org/10.1080/09523360802496148

Mao, L. L., \& Huang, H. (2016) Social impact of Formula One Chinese Grand Prix: A comparison of local residents' perceptions based on the intrinsic dimension. Sport Management Review, 19(3), 306-318. DOI: https://dx.doi.org/10.1016/j.smr.2015.08.007

Middleton, V. T. C. (1988). Marketing and travel and tourism. Oxford, UK: Heinemann.

Mihalik, B. J., \& Simonetta, L. (1998). Resident perceptions of the 1996 Summer of Olympic Games- Year II. Festival Management \& Event Tourism, 5, 9-19. DOI: https://doi.org/10.1177\%2F1356766714521809

Mihalik, B. J., \& Simonetta, L. (1999). A midterm assessment of the host population's perceptions of the 1996 Summer Olympics: support, attendance, benefits, and liabilities. Journal of Travel Research, 37(3), 244-248. DOI: http://dx.doi.org/10.1177/004728759903700305

Nunkoo, R., \& Gursoy, D. (2012). Residents' support for tourism: An identity perspective. Annals of Tourism Research, 39(1), 243-268. DOI: http://doi.org/10.1016/j.annals.2011.05.006

Owen, J.G. (2005). Estimating the cost and benefit of hosting Olympic Games: What can Beijing expect from its 2002 Games? The Industrial Geographer, 1-18.

Pappas, N. (2014) Hosting mega events: Londoners' support of the 2012 olympics. Journal of Hospitality \& Tourism Management, 21, 10-17. DOI: https://doi.org/10.1016/j.jhtm.2014.02.001

Porter, P. K., \& Fletcher, D. (2008). The economic impact of the Olympic Games: Ex ante predictions and ex poste reality. Journal of Sport Management, 22, 470-486. DOI: http://dx.doi.org/10.1123/ism.22.4.470

Pranic, L., Petric, L., \& Cetinic, L. (2012). Host population perceptions of the social impacts of sport tourism events in transition countries: Evidence from Croatia. International Journal of Event and Festival Management, 3(3), 236-256. DOI: https://doi.org/10.1108/17582951211262684

Prayag, G., Hosany, S., Nunkoo, R., \& Alders, T. (2013). London residents' support for the 2012 Olympic Games: the mediating effect of overall attitude. Tourism Management, 36, 629e640. DOI:

https://dx.doi.org/10.1016/j.tourman.2012.08.003 
Preuss, H. (2004). The Economics of Staging the Olympics: A Comparison of the Games, 1972-2008. Edward Elgar Publishing Ltd.

Preuss, H. (2006). Winners and losers of the olympic games. In B. Houlihan. Ed: Sport \& Society (415-438). London: Thousand Oaks, CA \& New Dehli.

Preuss, H. (2007). The Conceptualisation and Measurement of Mega Sport Event Legacies. Journal of Sport \& Tourism, 12(3-4), 207-228. DOI: https://doi.org/10.1080/14775080701736957

Preuss, H., \& Arne Solberg, H. (2006). Attracting major sporting events: The role of local residents. European Sport Management Quarterly, 6, 391-411. DOI: https://doi.org/10.1080/16184740601154524

Ritchie, J. B., \& Lyons, M. (1990). Olympulse VI: a post-event assessment of resident reaction to the XV Olympic Winter Games. Journal of Travel Research, 28(3), 14-23. DOI: http://dx.doi.org/10.1177/004728759002800303.

Rodrigues, C., \& Melo, A. (2012). The Triple Helix Model as an Instrument of Local Response to the Economic $\begin{array}{lllll}\text { Crisis. European Planning } & \text { Studies, } & \text { 1483-1496. }\end{array}$ https://doi.org/10.1080/09654313.2012.709063

Rossi, C. (2013). Apoio e resistência popular à realização de megaeventos: algumas lições para o Brasil. Artigo de Mestrado. Mestrado Profissional em Gestão e Políticas Públicas. Escola de Administração Pública de São Paulo. Fundação Getúlio Vargas, São Paulo. 2013. Disponível em: < http://bibliotecadigital.fgv.br/dspace/bitstream/handle/10438/11190/Artigo_Carla_Rossi_30_set_2013.pdf?sequence=1>. Acesso em: 10 mar 2017.

Santos, R. A., \& Souza, N. S. (2012). Copa do Mundo e Olimpíadas no Brasil: perspectivas de crescimento e desenvolvimento do turismo brasileiro. Revista Científica Eletrônica de Turismo, 16.

Smith, N. (2005). The New Urban Frontier. London: Routledge.

Solberg, H. A. \& Preuss, H. (2007). Major sports events and long-term tourism impacts. Journal of Sport Management, 21 (2), 213-234. DOl: https://doi.org/10.1123/jsm.21.2.213

Soutar, G. N., \& McLeod, P. B. (1993). Residents' perception on impacts of the America's Cup. Annals of Tourism Research, 20(3), 571-582. DOI: https://dx.doi.org/10.1016/0160-7383(93)90010-Z.

Souza, A. P. P., Souza, D. L., Castro, S. B. E., \& Mezzadri, F. M. (2013). Megaeventos esportivos: competições esportivas ou políticas/econômicas? Motrivivência, 41, 101-114. DOI: https://doi.org/10.5007/21758042.2013v25n41p101

Toohey, C. (2008). The Sydney Olympics: Striving for Legacies - Overcoming Short-Term Disappointments and Long-Term Deficiencies. The International Journal of The History of Sport, 25(14), 1953-1971. DOI: https://doi.org/10.1080/09523360802439270

Toohey, K., \& Veal, A. J. (2007). The Olympic games: A social science perspective. 2nd ed. Wallingford: CAB International.

Van Niekerk, M. (2017). Contemporary issues in events, festivals and destination management. International Journal of Contemporary Hospitality Management, 29(3), 842-847. DOI: https://doi.org/http://dx.doi.org/10.1108/MRR-09-2015-0216

Vetitnev, A. M. \& Bobina, N. (2015). Residents' perceptions of the 2014 Sochi Olympic Games, Leisure Studies, 36(1), 108-118. DOI: https://doi.org/10.1080/02614367.2015.1105857

Waitt, G. (2003). Social impacts of the Sydney Olympics. Annals of Tourism Research, 30(1), 194-215. DOI: https://doi.org/10.1016/S0160-7383(02)00050-6

Walton, H., Longo, A., \& Dawson, P. (2008). A contingent valuation of the 2012 London Olympic Games: A regional perspective. Journal of Sports Economics, 9(3), 304-317. DOI: https://doi.org/10.1177\%2F1527002507308769

Whitson, D. \& Horne, J. (2006). Underestimated costs and overestimated benefits? comparing the outcomes of sports mega-events in Canada and Japan. Sociological Review, 54, 73-89. DOI: https://doi.org/10.1111\%2Fj.1467-954X.2006.00654.X

Williams, J., \& Lawson, R. (2001). Community issues and resident opinions of tourism. Annals of Tourism Research, 28(2), 269-290. DOI: http://dx.doi.org/10.1016/S0160-7383(00)00030-X 
Xie, K. L. , \& Lee, J.-S. (2013). Toward the perspective of cognitive destination image and destination personality: The case of Beijing. Journal of Travel \& Tourism Marketing, 30(6), 538-556. DOI: https://doi.org/10.1080/10548408.2013.810993

Zhou, Y., \& Ap, J. (2009). Residents' perceptions towards the impacts of the Beijing 2008 Olympic Games. Journal of Travel Research, 48(1), 78-91. DOI: https://doi.org/10.1177/0047287508328792

Zouain, D. M., Lohmann, P. B., Virkki, K.B., \& Bezerra, M.F. (2018). Juegos Olímpicos Rio 2016 y Copa del Mundo 2014: un análisis comparativo de la demanda turística doméstica e internacional. Estudios y Perspectivas en Turismo, 27, 121-139.

\section{Information about the authors}

\section{Deborah Moraes Zouain,}

She is a post-doctoral student in Civil Engineering (completion in 2019), Fluminense Federal University (UFF). She holds a PhD in Production Engineering (COPPE/UFRJ) and a Master's Degree in Education, Federal University of Rio de Janeiro (UFRJ). She graduated in Administration, Getulio Vargas Foundation (FGV), Rio de Janeiro and in Law, University of the State of Rio de Janeiro (UERJ). She is a Professor of the Post-Graduation Programme in Administration, UNIGRANRIO and coordinator of the Centre for Tourism Research. Contribution: research design and discussion.

E-mail: deborahzouain@gmail.com

ORCID: https://orcid.org/0000-0003-4813-9741

Paola Bastos Lohmann,

She is a PhD student in Tourism, University of Aveiro, Portugal (completion in 2020). She holds a Master's Degree in Business Management, Getulio Vargas Foundation (FGV). She graduated in Tourism, Fluminense Federal University (UFF). She is a researcher at UNIGRANRIO Centre for Tourism Research. She is a Reverse doctoral grant holder, FAPERJ - 2018.

Contribution: data collection, data analysis and discussion

E-mail: paolalohmann@gmail.com

ORCID: https://orcid.org/0000-0001-8818-3099

\section{Gabriela De Laurentis Cardoso,}

She is a Master's student in the Post-graduation Programme in Design, Superior School of Industrial Design, UERJ (PPDESDI). She attended a Master's Degree programme in Market Research, Media and Public Opinion, University of Entrepreneurial and Social Sciences (UCES), Buenos Aires. She graduated in Visual Programming by UniverCidade, Rio de Janeiro. She is a researcher at UNIGRANRIO Centre for Tourism Research.

Contribution: literature review, data analysis and discussion

E-mail: gabydelaurentis@yahoo.com

ORCID: https://orcid.org/0000-0002-9049-2904

\section{Kaarina Barbosa Virkki,}

She completed post-graduate degrees in Business Administration, Getulio Vargas Foundation (FGV), and in Marketing, Brazilian Institute of Markets and Capitals (IBMEC). She graduated in Tourism, Fluminense Federal University (UFF). She is a researcher at UNIGRANRIO Centre for Tourism Research.

Contribution: literature review, data collection and discussion

E-mail: kaarina.virkki@gmail.com

ORCID: https://orcid.org/0000-0002-4043-9670

\section{Marcela Cohen Martelotte,}

She completed post-doctoral studies, COPPE/UFRJ. She holds a PhD in Electrical Engineering, PUC-Rio, a Master's Degree in Business Administration, Getulio Vargas Foundation (FGV), RJ and a Master's Degree in Electrical Engineering, PUC-Rio. She graduated in Statistics, National School of Statistics (ENCE). She is an Adjunct Professor at the Department of Production Engineering, Fluminense Federal University (EEIMVR)

Contribution: data analysis and discussion

E-mail: marcela.cohen@gmail.com

ORCID: https://orcid.org/0000-0002-1580-8948 